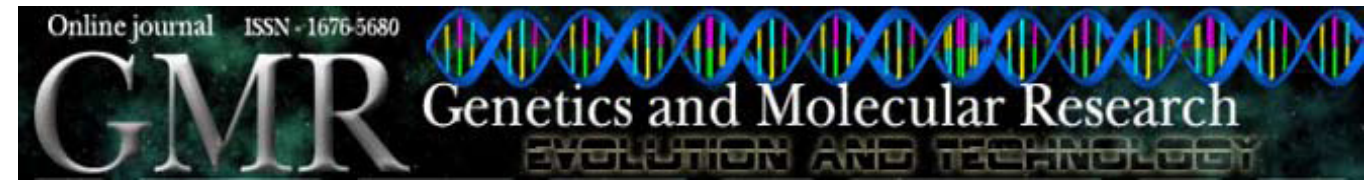

\title{
Genetic trend estimates of meat quality traits in a male broiler line
}

\author{
G.B. Mourão ${ }^{1}$, L.G. Gaya ${ }^{2}$, J.B.S. Ferraz ${ }^{3}$, E.C. Mattos ${ }^{3}$, A.M.M.A. Costa ${ }^{3}$, \\ T. Michelan Filho ${ }^{4}$, O.C. Cunha Neto ${ }^{2}$, A.M. Felício ${ }^{3}$ and J.P. Eler ${ }^{3}$ \\ ${ }^{1}$ Escola Superior de Agricultura Luiz de Queiroz, \\ Universidade de São Paulo, Piracicaba, SP, Brasil \\ ${ }^{2}$ Departamento de Zootecnia, Centro de Educação Superior do Oeste, \\ Universidade do Estado de Santa Catarina, Chapecó, SC, Brasil \\ ${ }^{3}$ Grupo de Melhoramento Animal e Biotecnologia, \\ Faculdade de Zootecnia e Engenharia de Alimentos da \\ Universidade de São Paulo, Pirassununga, SP, Brasil \\ ${ }^{4}$ Aviagen do Brasil Ltda., Rio Claro, SP, Brasil \\ Corresponding author: L.G. Gaya \\ E-mail: lggaya@yahoo.com.br
}

Genet. Mol. Res. 7 (3): 749-761 (2008)

Received June 9, 2008

Accepted July 4, 2008

Published August 26, 2008

\begin{abstract}
The present research was conducted to estimate the genetic trends for meat quality traits in a male broiler line. The traits analyzed were initial $\mathrm{pH}, \mathrm{pH}$ at $6 \mathrm{~h}$ after slaughter, final $\mathrm{pH}$, initial range of falling $\mathrm{pH}$, final range of falling $\mathrm{pH}$, lightness, redness, yellowness, weep loss, drip loss, shrink loss, and shear force. The number of observations varied between 618 and 2125 for each trait. Genetic values were obtained by restricted maximum likelihood, and the numerator relationship matrix had 107,154 animals. The genetic trends were estimated by regression of the broiler average genetic values with respect to unit of time (generations), and the average genetic trend was estimated by regression coefficients. Generally, for the traits analyzed, small genetic trends were obtained, except for drip loss and shear force, which were higher. The small magnitude of the trends found could be a consequence of the absence of selection for meat quality traits in the line analyzed. The estimates of genetic
\end{abstract}


trends obtained were an indication of an improvement in the meat quality traits in the line analyzed, except for drip loss.

Key words: Animal breeding; Broiler; Genetic trend; Meat quality; Poultry quality

\section{INTRODUCTION}

Brazilian broiler production is an industry that has had great progress in the last few decades. In the last years, broiler production in Brazil grew more than $40 \%$, reaching more than 10 million tons in 2007 (AviSite, 2008). It represents $45.3 \%$ of the total amount of meat produced in Brazil and close to $12 \%$ of the total broiler produced in the world. This development, in Brazil and worldwide, resulted not only from the number of producers and their size, but was mainly due to the intense selection process that has occurred since the beginning of the use of crossbreeding in poultry production.

However, the selection for economic traits, especially growth rate, may induce several changes in broiler meat quality (Dransfield and Sosnicki, 1999). According to Sams (1999) and to Solomon et al. (1998), broiler meat quality is influenced by several factors, but mainly by genetics. In this manner, in agreement with Dirinck et al. (1996), one of the major problems met by the processing industry is PSE meat, where the initials refer to the words pale, soft and exudative. The PSE phenomenon is prognosticated by changes in some meat quality traits, involving the degeneration of meat functional properties due to the fast post-mortem glycolysis (Wismer-Pedersen, 1959), accelerating the fall in muscle $\mathrm{pH}$ while the carcass temperature is still high (Barbut, 1997; Fernandez et al., 2002). The combination of both circumstances can lead to the denaturation of muscle proteins (Molette et al., 2003), which causes lower water retaining capacity, and consequently a paler and firmer meat at cooking, fundamental attributes for the processing of the meat by the industry and for its acceptance by the consumer.

The study of genetic trends is an important factor for monitoring the selection process. It can entail a graphic representation of the changes observed in the average genetic values of the species studied for a trait during selection (Ferraz and Eler, 2000). According to Costa et al. (2001), the knowledge of genetic trends allows the visualization of changes caused by selection in a trait, which permits the analysis of the efficiency of the applied selection procedures and quantification of the genetic changes over time, besides allowing the correction of eventual mistakes in selection (Van Melis et al., 2001). Thus, the study of genetic trends for meat quality traits enables the evaluation and the orientation of selection applied over generations. Moreover, genetic trends in broilers are rarely presented in the literature (Costa et al., 2005; Gaya et al., 2005; Rezende et al., 2005), which emphasizes the importance of this study.

Therefore, the objective of the present study was to estimate the genetic trends for meat quality traits in a male broiler line with respect to selection generations.

\section{MATERIAL AND METHODS}

\section{Data origin}

In the current study, a dataset from sibs from an elite flock that had undergone selection 
for development of a sire line was used. The use of carcass information for these sibs comprises a sib test program, which aids in choosing the best animals during the selection of that elite flock. Pedigree chicks were housed and raised as recommended by the company guidelines. The control of individual pedigree was made at hatching via wingbands that contained a number and the corresponding bar code with all necessary information for individual identification.

\section{Data collection}

At 44 days of age, from May 2005 to March 2006, each flock of sibs was transported to the Experimental Processing Plant of the University of São Paulo (Pirassununga, SP, Brazil). The birds were submitted to a minimum of $10 \mathrm{~h}$ of feed withdrawal prior to slaughter. The transportation of the broilers to the processing plant lasted about $6 \mathrm{~h}$. The voltage used for electric shock in the immobilization of the birds was $40 \mathrm{~V}$, at $60 \mathrm{~Hz}$ and an average of $2 \mathrm{amp}$ per bird, for $9 \mathrm{~s}$. Bleeding of the birds lasted $3 \mathrm{~min}$. Prior to feather removal, birds were immersed in water at $57^{\circ} \mathrm{C}$ for $2 \mathrm{~min}$.

The identification of each animal and data collection were automatically recorded using portable terminals and bar code readers. A software program developed by Gaya et al. (2006) was used to record the identification of the individuals and to collect the meat quality data. Approximately 2200 broilers were submitted to data collection of meat quality traits.

Data from the sib test flock were all measured in the pectoralis major muscle and collected as follows.

\section{pH measures}

Initial $\mathrm{pH}\left(\mathrm{pH}_{\mathrm{i}}\right)$ was measured at 15 min after slaughter, $\mathrm{pH}$ at $6 \mathrm{~h}\left(\mathrm{pH}_{6}\right)$ was measured at $6 \mathrm{~h}$ after slaughter and final $\mathrm{pH}\left(\mathrm{pH}_{\mathrm{f}}\right)$ was measured at $24 \mathrm{~h}$ after slaughter, all determined in the cranial-ventral portion of the muscle, using a digital $\mathrm{pH}$ meter. After $\mathrm{pH}_{\mathrm{i}}$ measurement, carcasses were submitted to pre-chilling by immersion in cold water at $10^{\circ} \mathrm{C}$ for $10 \mathrm{~min}$ and afterward stored in cooling chambers $\left(0\right.$ to $\left.2^{\circ} \mathrm{C}\right)$. Six hours after slaughter, carcasses were measured for $\mathrm{pH}_{6}$ recording and kept under refrigeration until the next day, when they were sent to a climatized deboning room $\left( \pm 15^{\circ} \mathrm{C}\right)$ and $\mathrm{pH}_{\mathrm{f}}$ was recorded. Based on these measurements, initial range of falling $\mathrm{pH}\left(\mathrm{R}_{\mathrm{i}}\right)$ was calculated as $\mathrm{pH}_{6}$ less $\mathrm{pH}_{\mathrm{i}}$, and the final range of falling $\mathrm{pH}\left(\mathrm{R}_{\mathrm{f}}\right)$ was calculated as $\mathrm{pH}_{\mathrm{f}}$ less $\mathrm{pH}_{\mathrm{i}}$.

\section{Color parameters}

Color parameters were measured at $24 \mathrm{~h}$ after slaughter using a portable colorimeter and the lightness $\left(\mathrm{L}^{*}\right)$, redness $\left(\mathrm{a}^{*}\right)$ and yellowness $\left(\mathrm{b}^{*}\right)$ scale from the CIELab System, with light source $\mathrm{D}_{65}$, observation angle of $10^{\circ}$ and measuring cell opening of $30 \mathrm{~mm}$. The measurements were recorded at three different points on the muscle, on the sample surface, considering the mean of these three points as the determined value.

\section{Water losses}

The water losses determined in this study were weep, drip and shrink losses of the meat (WL, DL, SL, respectively). WL was recorded by weighing the muscle samples after deboning, 
which were supported in a net and enclosed in a plastic bag full of air. The samples were stored under refrigeration $\left(0\right.$ to $\left.2^{\circ} \mathrm{C}\right)$ and after $24 \mathrm{~h}$ were again weighed. The difference, in percentage, between initial and final weight corresponded to WL. DL was determined by storing muscle samples in plastic bags at $24 \mathrm{~h}$ after slaughter, and keeping them in a freezer at $-18^{\circ} \mathrm{C}$. The samples were defrosted in a refrigerator at $4^{\circ} \mathrm{C}$ and then weighed. The difference, in percentage, between initial and final weight corresponded to DL. SL was recorded using the same samples as for DL, which, after being defrosted and weighed, were baked in an electric oven until an internal temperature of $72^{\circ} \mathrm{C}$ was reached. The samples were then cooled at room temperature and again weighed. The difference, in percentage, between initial and final weight corresponded to SL.

\section{Shear force}

This trait was determined using the same samples as for SL, which, after being baked and cooled, were submitted to shear force (SF) analysis. Four parallelepipeds measuring $2 \times 2$ $\mathrm{x} 1 \mathrm{~cm}$ were removed from each sample, which were sheared by a Warner Bratzler blade. The mean of SF for the 4 parallelepipeds was considered as sample SF, given in $\mathrm{kg}$. The samples were positioned perpendicular to the blade.

\section{Statistical analysis}

The data were processed at the Animal Breeding Group of the Department of Basic Sciences in the School of Animal Science and Food Engineering, São Paulo University, in Pirassununga, Brazil. Extreme values, outliers, were identified using the box-plot procedure and removed from the data set. The descriptive statistics were calculated by PROC MEANS of the Statistical Analysis System software (SAS Institute, 1999). The genetic values were obtained by the restricted maximum likelihood method, using a full animal model and the MTDFREML software (Boldman et al., 1995). Using this software, based on meat quality information from sib individuals, it was possible to determine the genetic values of these animals and of all their available relatives. The numerator relationship matrix had 107,154 animals. The mathematical model used in the one-trait analysis was: $\mathrm{Y}=\mathrm{Xb}+\mathrm{Zu}+\mathrm{e}$, in which $\mathrm{Y}$ is the dependent variable vector; $\mathrm{X}$ is the incidence matrix for fixed effects; $b$ is the fixed effect vector; $Z$ is the incidence matrix for random effects; $u$ is the genetic value random vector, and e is the residual effect vector, $\operatorname{NID}\left(0, \sigma^{2}\right)$.

The fixed effects (vector $b$ ) considered for $\mathrm{pH}_{\mathrm{i}}$ and $\mathrm{pH}_{\mathrm{f}}$ were flock and mating group of their parents; for $\mathrm{pH}_{6}, \mathrm{~L}^{*}, \mathrm{a}^{*}$ and $\mathrm{DL}$ they were flock, mating group of their parents and sex; for $\mathrm{R}_{\mathrm{i}}$ and $\mathrm{R}_{\mathrm{f}}$ they were flock, mating group of their parents and season at slaughter; for WL, SL and SF they were flock and sex, and for $b^{*}$ the single fixed effect considered was flock. The significance of these effects was estimated by PROC GLM of the Statistical Analysis System software (SAS Institute, 1999), and was considered to be significant $(\mathrm{P}<0.0001)$. The random effect (vector $u$ ) considered was direct additive genetic effect.

Genetic trends of meat quality traits were estimated by regression of the broiler average genetic values with respect to unit of time (generations). The average genetic trend was estimated by regression coefficients, where significance was calculated by PROC GLM of the Statistical Analysis System software (SAS Institute, 1999), and was considered to be significant (P< 0.0001). The number of generations in the pedigree file was counted by the CALGERA software (Mourão et al., 2004), pointing to 38 generations, in which 6 were the main ones and homoge- 
neous, involving the mating of individuals from the same generation, and the others were intermediate, involving the mating of individuals from different generations. Each generation had an average of 2471.5 animals. Regression coefficients and their determination coefficients were estimated by PROC REG of the Statistical Analysis System software (SAS Institute, 1999).

\section{RESULTS AND DISCUSSION}

The descriptive statistics (i.e., number of observations, mean, standard deviation, coefficient of variation, and minimum and maximum values) for the traits studied are presented in Table 1.

\begin{tabular}{|c|c|c|c|c|c|c|}
\hline Trait & $\mathrm{N}$ & Mean & SD & CV (\%) & MIN & MAX \\
\hline $\mathrm{pH}_{\mathrm{i}}$ & 938 & 6.12 & 0.19 & 3.02 & 5.64 & 6.62 \\
\hline $\mathrm{pH}_{6}$ & 932 & 5.96 & 0.18 & 2.94 & 5.56 & 6.45 \\
\hline $\mathrm{pH}_{\mathrm{f}}$ & 2107 & 5.80 & 0.13 & 2.32 & 5.44 & 6.20 \\
\hline $\mathrm{R}_{\mathrm{i}}$ & 618 & 0.26 & 0.16 & 61.06 & 0.01 & 0.78 \\
\hline $\mathrm{R}_{\mathrm{f}}$ & 777 & 0.32 & 0.15 & 46.05 & 0.01 & 0.59 \\
\hline $\mathrm{L}^{*}$ & 2130 & 56.07 & 3.00 & 5.30 & 47.62 & 63.98 \\
\hline$a^{*}$ & 2116 & 5.35 & 1.10 & 20.59 & 2.26 & 8.54 \\
\hline $\mathrm{b}^{*}$ & 2098 & 13.59 & 2.12 & 15.59 & 7.77 & 19.20 \\
\hline WL (\%) & 2030 & 2.06 & 0.58 & 28.21 & 0.30 & 3.70 \\
\hline DL (\%) & 2125 & 6.46 & 3.22 & 49.82 & 0.40 & 18.30 \\
\hline SL (\%) & 2122 & 21.26 & 4.17 & 19.62 & 8.80 & 32.60 \\
\hline SF (kg) & 2113 & 1.21 & 0.41 & 33.94 & 0.30 & 2.50 \\
\hline
\end{tabular}

$\mathrm{pH}_{\mathrm{i}}=$ initial $\mathrm{pH} ; \mathrm{pH}_{6}=\mathrm{pH}$ at $6 \mathrm{~h}$ after slaughter; $\mathrm{pH}_{\mathrm{f}}=$ final $\mathrm{pH} ; \mathrm{R}_{\mathrm{i}}=$ initial range of falling $\mathrm{pH} ; \mathrm{R}_{\mathrm{f}}=$ final range of falling $\mathrm{pH} ; \mathrm{L}^{*}=$ lightness; $\mathrm{a}^{*}=$ redness; $\mathrm{b}^{*}=$ yellowness; $\mathrm{WL}=$ weep loss; $\mathrm{DL}=$ drip loss; $\mathrm{SL}=$ shrink loss; $\mathrm{SF}=$ shear force.

The values of genetic trends for $\mathrm{pH}_{\mathrm{i}}, \mathrm{pH}_{6}$ and $\mathrm{pH}_{\mathrm{f}}$ were positive, i.e., $+0.0003,+0.0015$ and +0.0032 units, respectively (Table 2 , Figures 1-3), representing an increasing trend for these traits, which at first seems to be favorable for $\mathrm{pH}$ measurements because for the development of the PSE condition a tendency genetically governed of falling $\mathrm{pH}$ is needed.

Table 2. Genetic trend estimates (in absolute values and in percent in relation to the mean) for meat quality traits.

\begin{tabular}{|c|c|c|}
\hline Trait & $\begin{array}{l}\text { Genetic trend } \\
(\mathrm{P}<0.0001)\end{array}$ & $\begin{array}{l}\text { Genetic trend in relation to the mean } \\
(\% / \text { generation })\end{array}$ \\
\hline $\mathrm{pH}_{\mathrm{i}}$ & +0.0003 & +0.004 \\
\hline $\mathrm{pH}_{6}$ & +0.0015 & +0.02 \\
\hline $\mathrm{pH}_{\mathrm{f}}$ & +0.0032 & +0.06 \\
\hline$R_{i}$ & -0.0003 & -0.001 \\
\hline$R_{f}$ & $-9.6620 \times 10^{-9}$ & -0.000003 \\
\hline $\mathrm{L}^{*}$ & -0.0027 & -0.005 \\
\hline $\mathrm{a}^{*}$ & +0.0058 & +0.1 \\
\hline $\mathrm{b}^{*}$ & +0.0003 & +0.002 \\
\hline WL & $-0.0007 \%$ & -0.03 \\
\hline DL & $-0.0378 \%$ & -0.6 \\
\hline SL & $+0.0154 \%$ & +0.07 \\
\hline $\mathrm{SF}$ & $-0.0033 \mathrm{~kg}$ & -0.3 \\
\hline
\end{tabular}




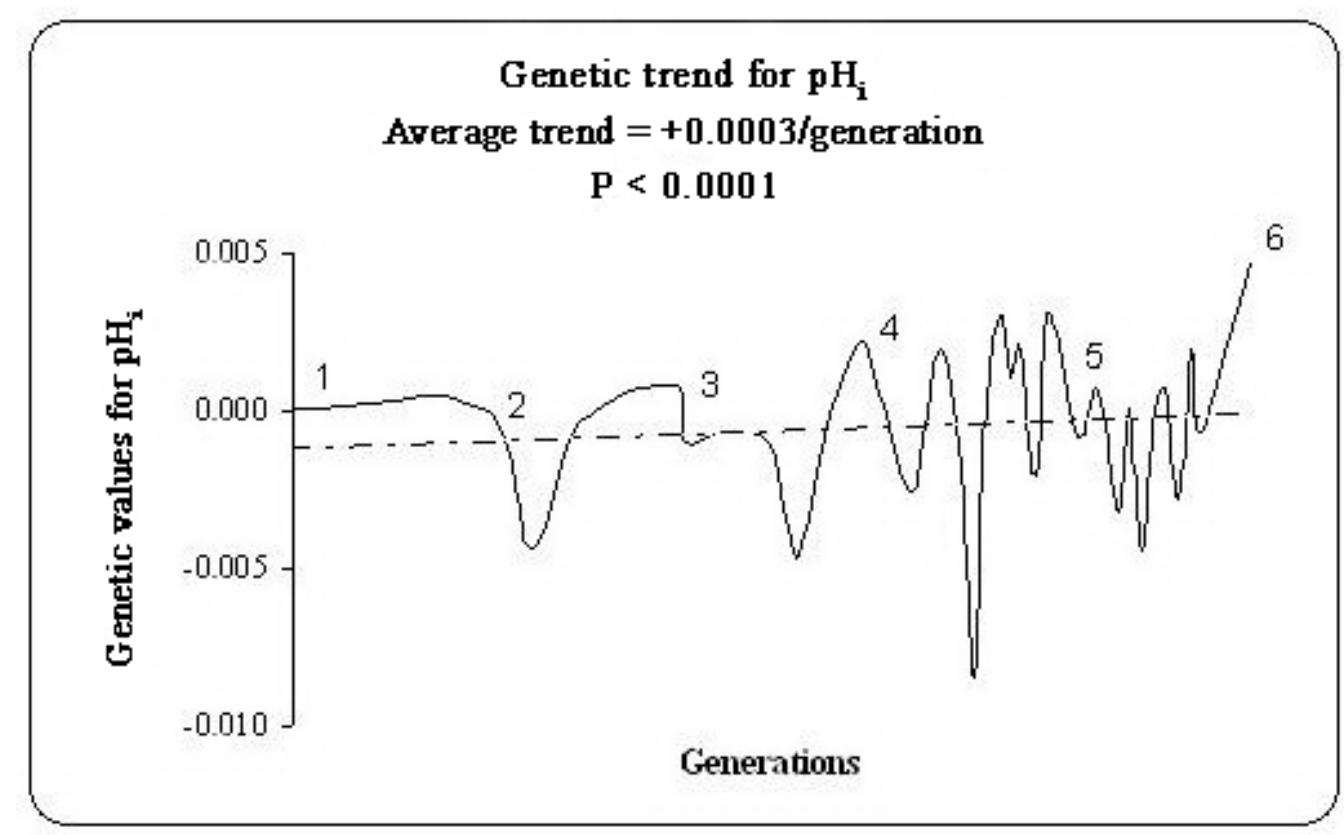

Figure 1. Genetic trend for initial $\mathrm{pH}\left(\mathrm{pH}_{\mathrm{i}}\right)$ over the generations studied estimated by regression analysis.

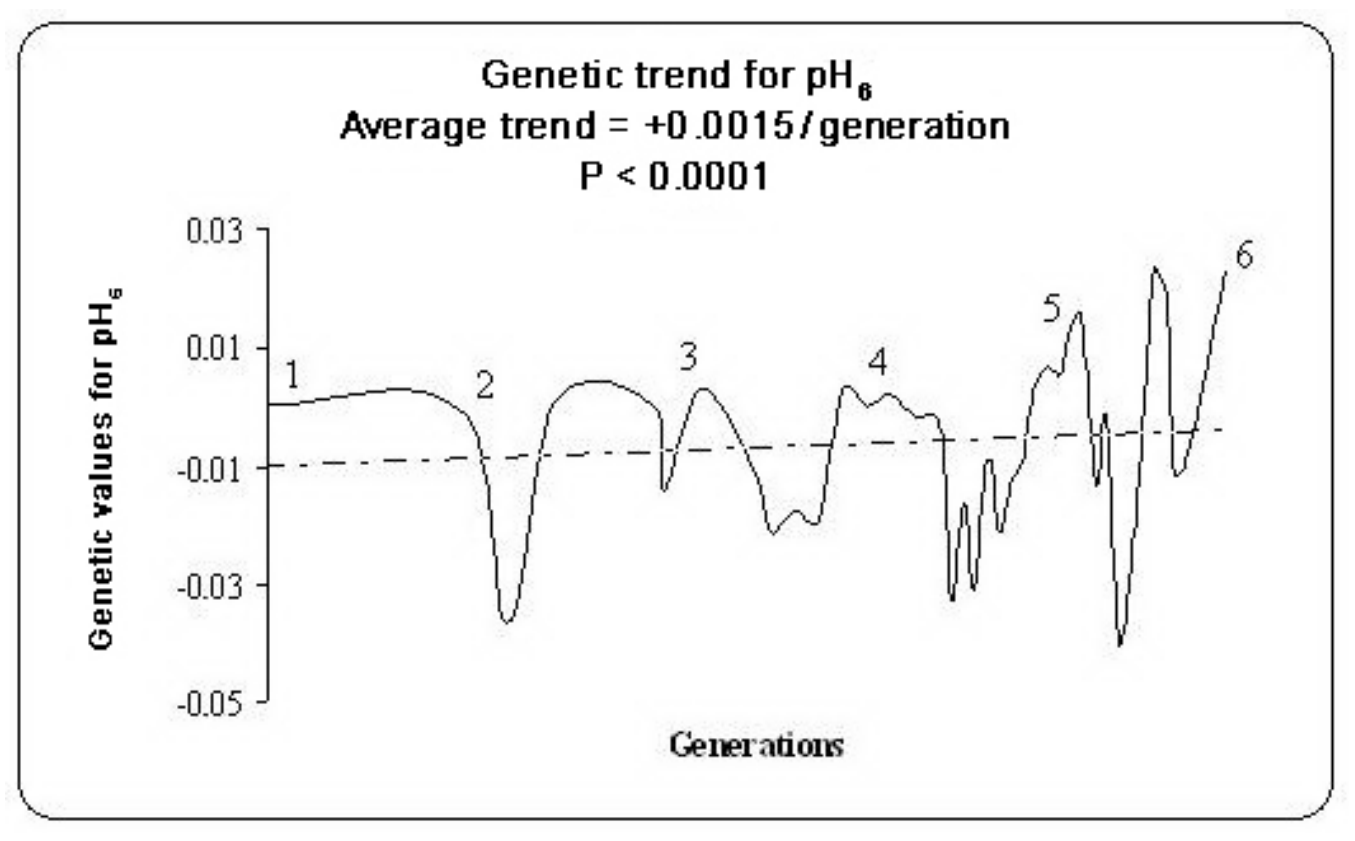

Figure 2. Genetic trend for $\mathrm{pH}$ at $6 \mathrm{~h}\left(\mathrm{pH}_{6}\right)$ over the generations studied estimated by regression analysis. 


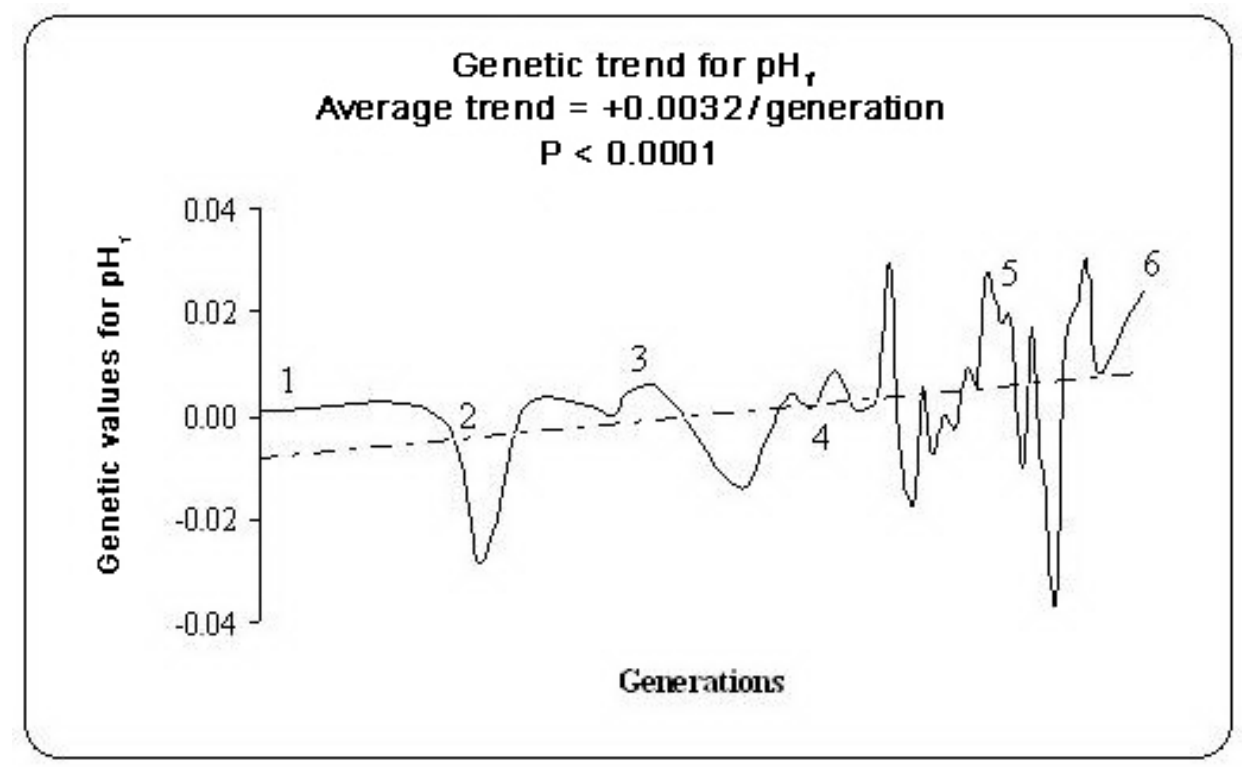

Figure 3. Genetic trend for final $\mathrm{pH}\left(\mathrm{pH}_{\mathrm{f}}\right)$ over the generations studied estimated by regression analysis.

In the same way, the values of genetic trends obtained for $\mathrm{a}^{*}, \mathrm{~b}^{*}$ and SL were positive, i.e., $+0.0058,+0.0003$ and $+0.0154 \%$, respectively (Table 2 , Figures $4-6$ ), which may be unfavorable for SL, whereas genetically, a decrease in this trait would be interesting.

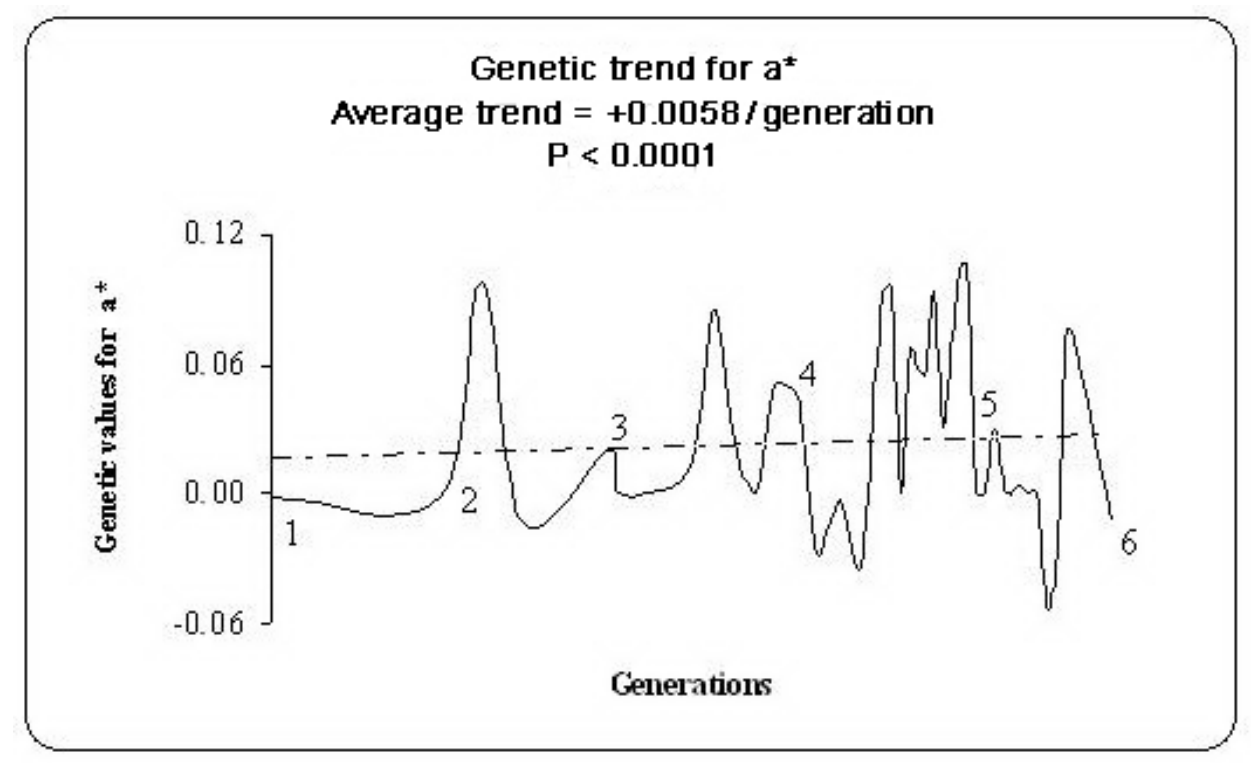

Figure 4. Genetic trend for redness $\left(a^{*}\right)$ over the generations studied estimated by regression analysis. 


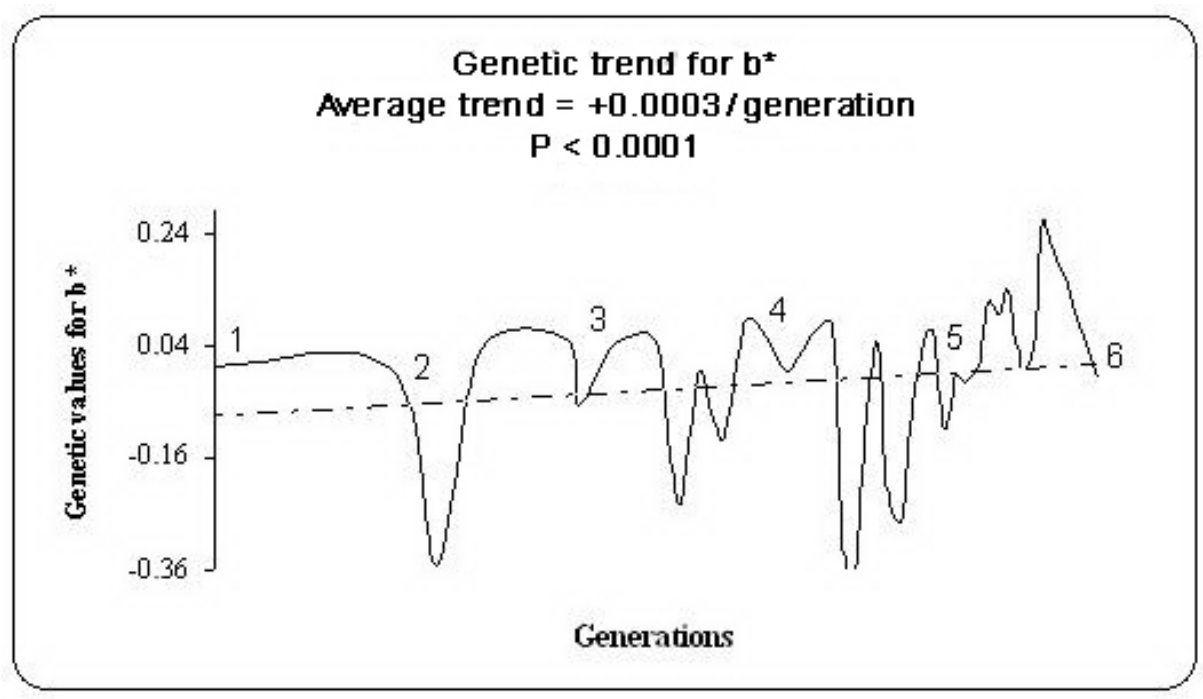

Figure 5. Genetic trend for yellowness $\left(b^{*}\right)$ over the generations studied estimated by regression analysis.

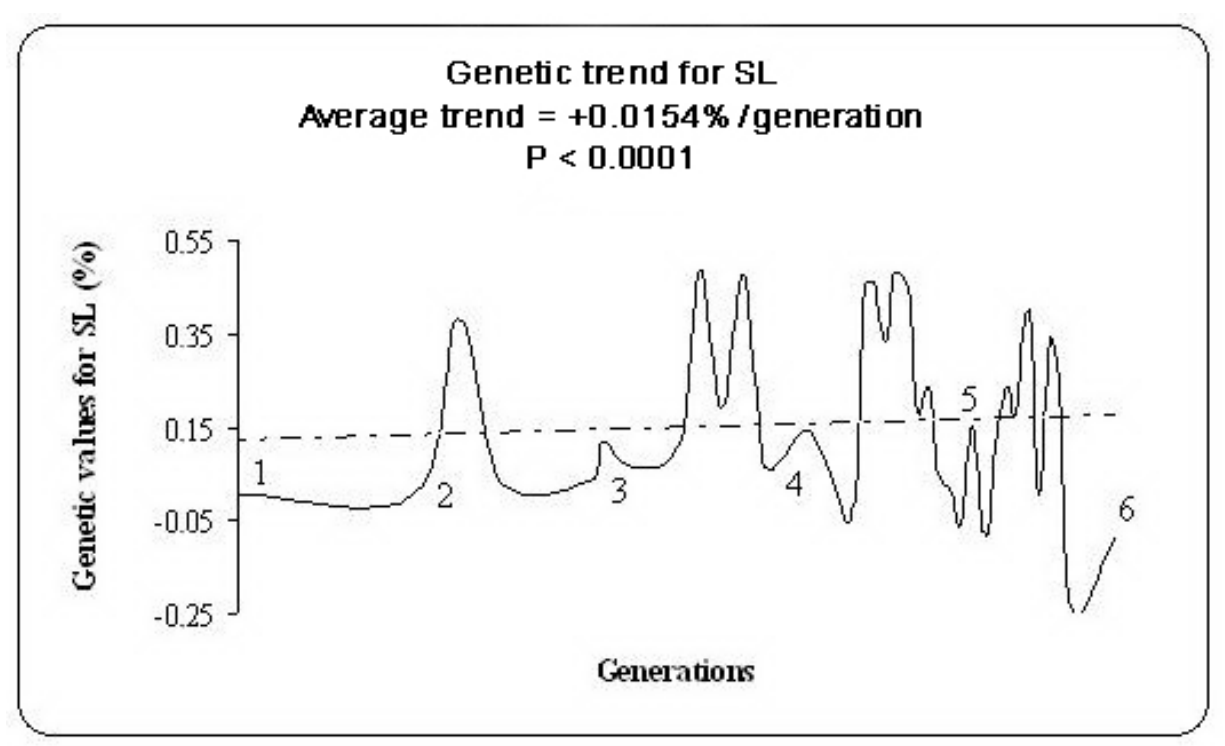

Figure 6. Genetic trend for shrink loss (SL) over the generations studied estimated by regression analysis.

For $\mathrm{R}_{\mathrm{i}}, \mathrm{R}_{\mathrm{f}}, \mathrm{L}^{*}, \mathrm{WL}, \mathrm{DL}$, and SF the values obtained for genetic trends were negative, i.e., $-0.0003,-9.6620 \times 10^{-9},-0.0027,-0.0007 \%,-0.0378 \%$ and $-0.0033 \mathrm{~kg}$, respectively (Table 2, Figures 7-12), representing a tendency toward a decrease in these traits. This seems to be favorable, since for the reduction of $\mathrm{R}_{\mathrm{i}}$ and $\mathrm{R}_{\mathrm{f}}$, in other words, smaller ranges of falling $\mathrm{pH}$, can contribute to the prevention of PSE meat, because greater and faster falling $\mathrm{pH}$ could 
be a determinant for the development of this condition (Barbut, 1997; Fernandez et al., 2002). Besides, the decrease in $\mathrm{L}^{*}$ is associated with a lesser paleness of meat, and a decrease in WL, DL and SF is associated with better meat yields and softness (Barbut, 1993; Anadón, 2002).

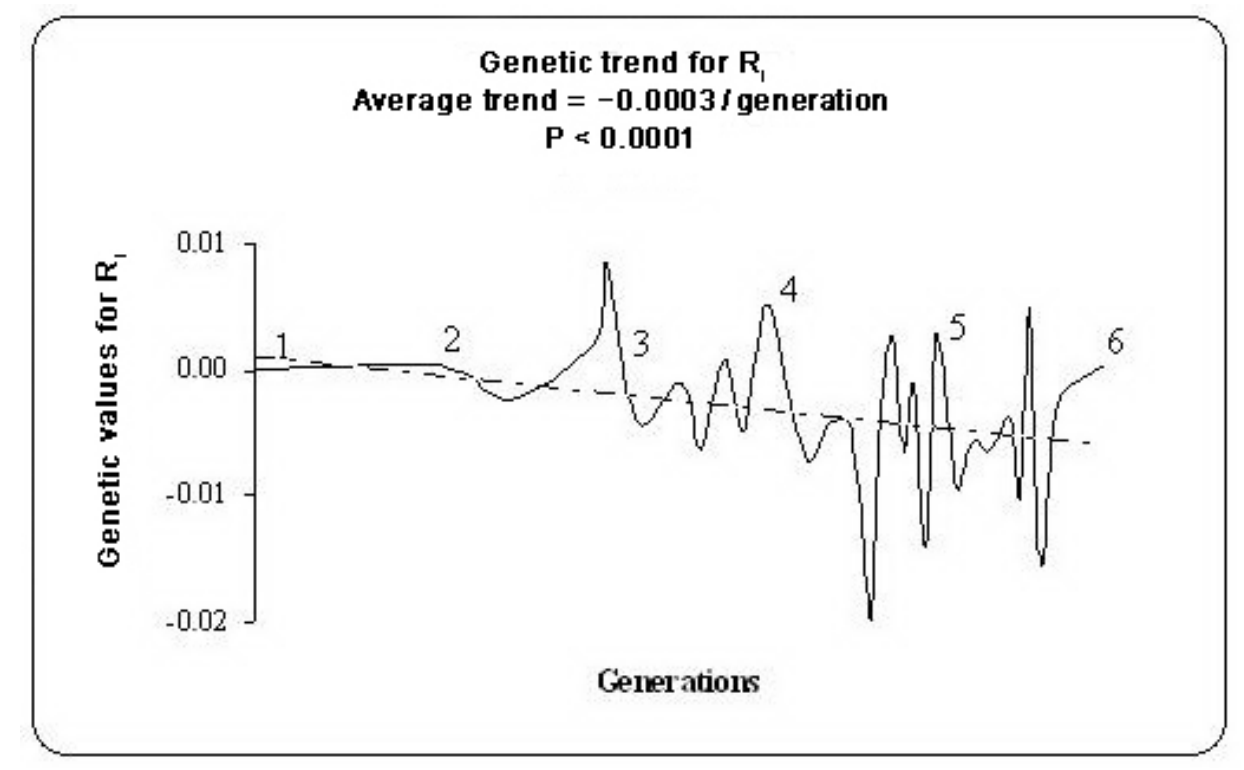

Figure 7. Genetic trend for initial range of falling $\mathrm{pH}\left(\mathrm{R}_{\mathrm{i}}\right)$ over the generations studied estimated by regression analysis.

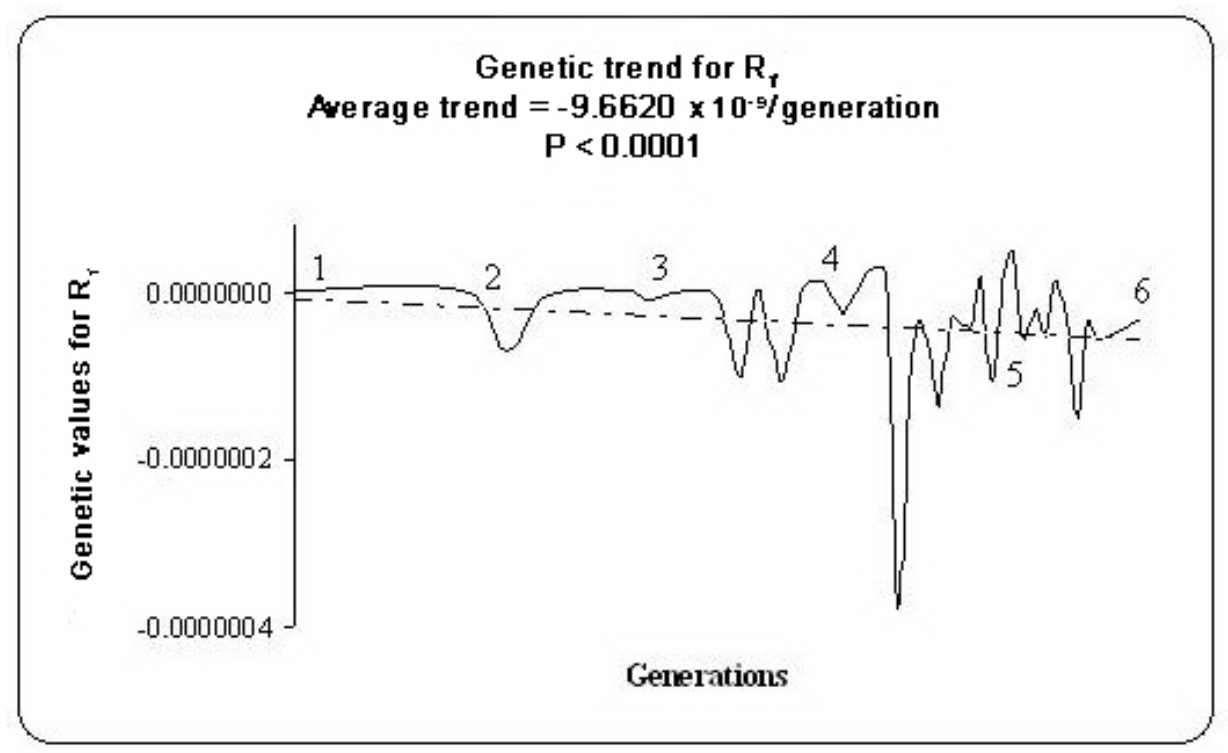

Figure 8. Genetic trend for final range of falling $\mathrm{pH}\left(\mathrm{R}_{\mathrm{f}}\right)$ over the generations studied estimated by regression analysis. 


\section{Genetic trend for $\mathrm{L}^{*}$ \\ Average trend $=-0.0027 /$ generation \\ $P<0.0001$}

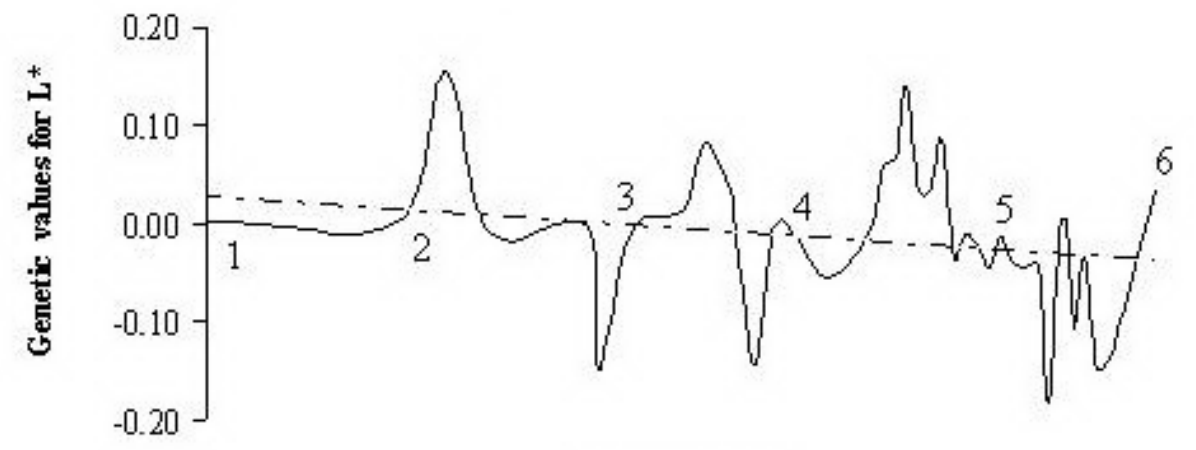

Generations

Figure 9. Genetic trend for lightness $\left(\mathrm{L}^{*}\right)$ over the generations studied estimated by regression analysis.

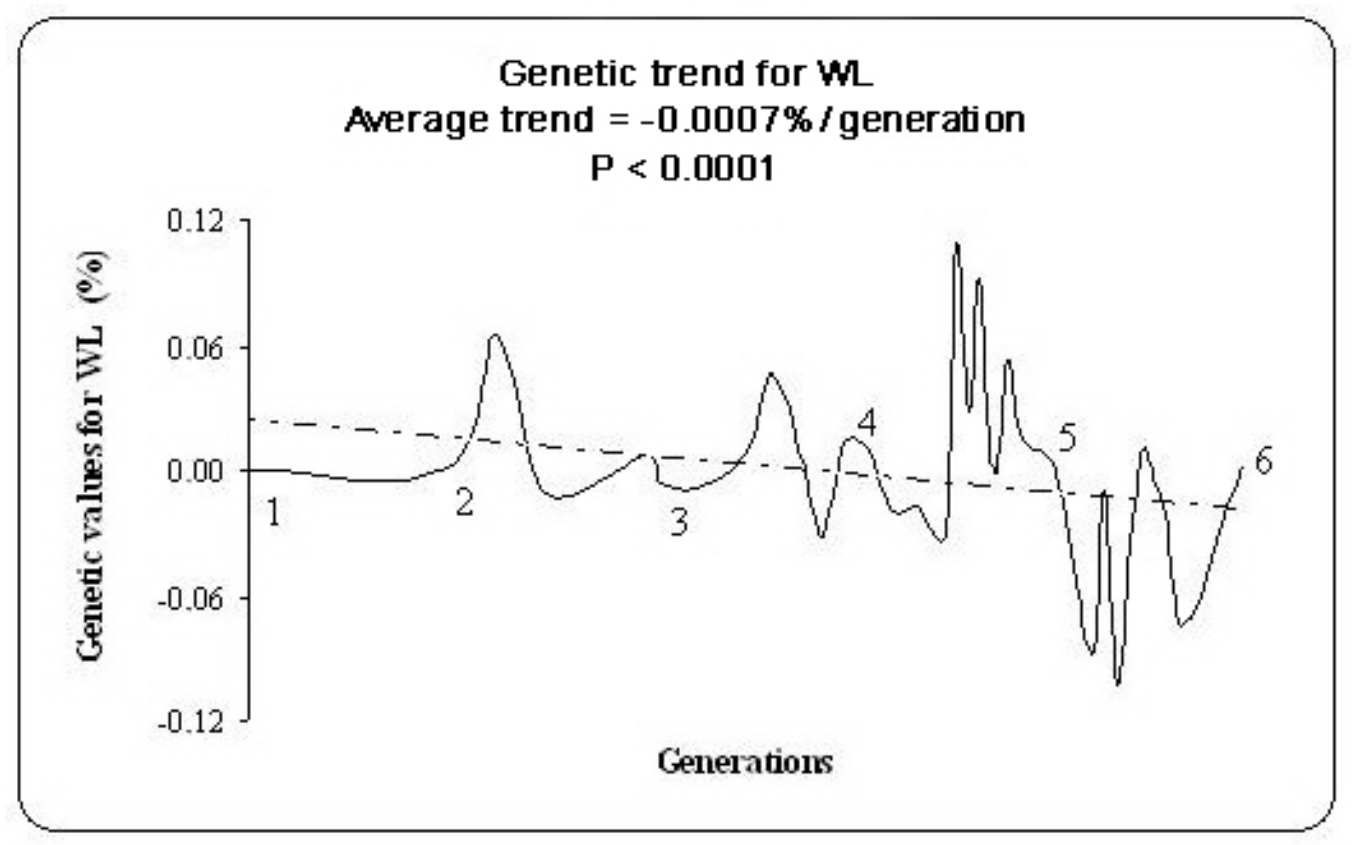

Figure 10. Genetic trend for weep loss (WL) over the generations studied estimated by regression analysis. 


\section{Genetic trend for DL Average trend $=-0.0378 \% / g e n e r a t i o n$ \\ $P<0.0001$}

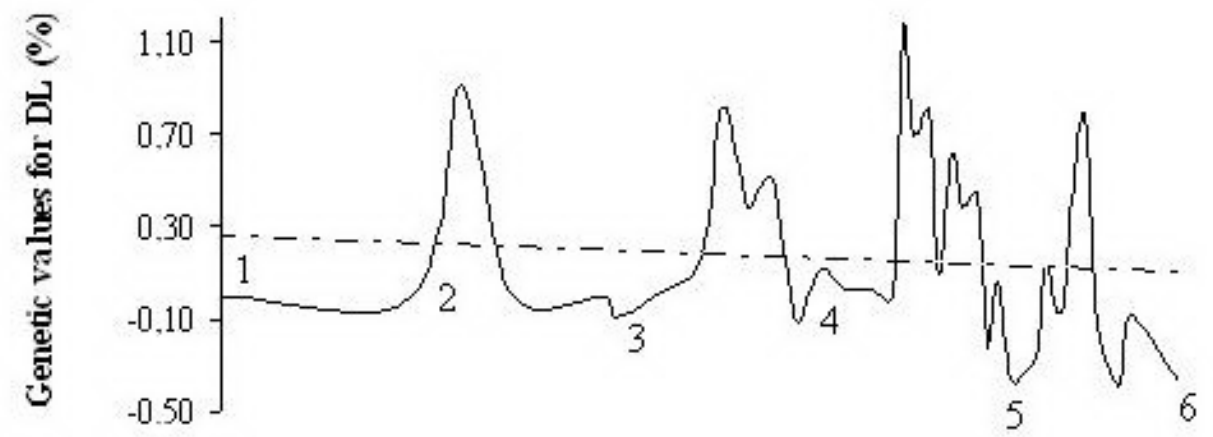

Generations

Figure 11. Genetic trend for drip loss (DL) over the generations studied estimated by regression analysis.

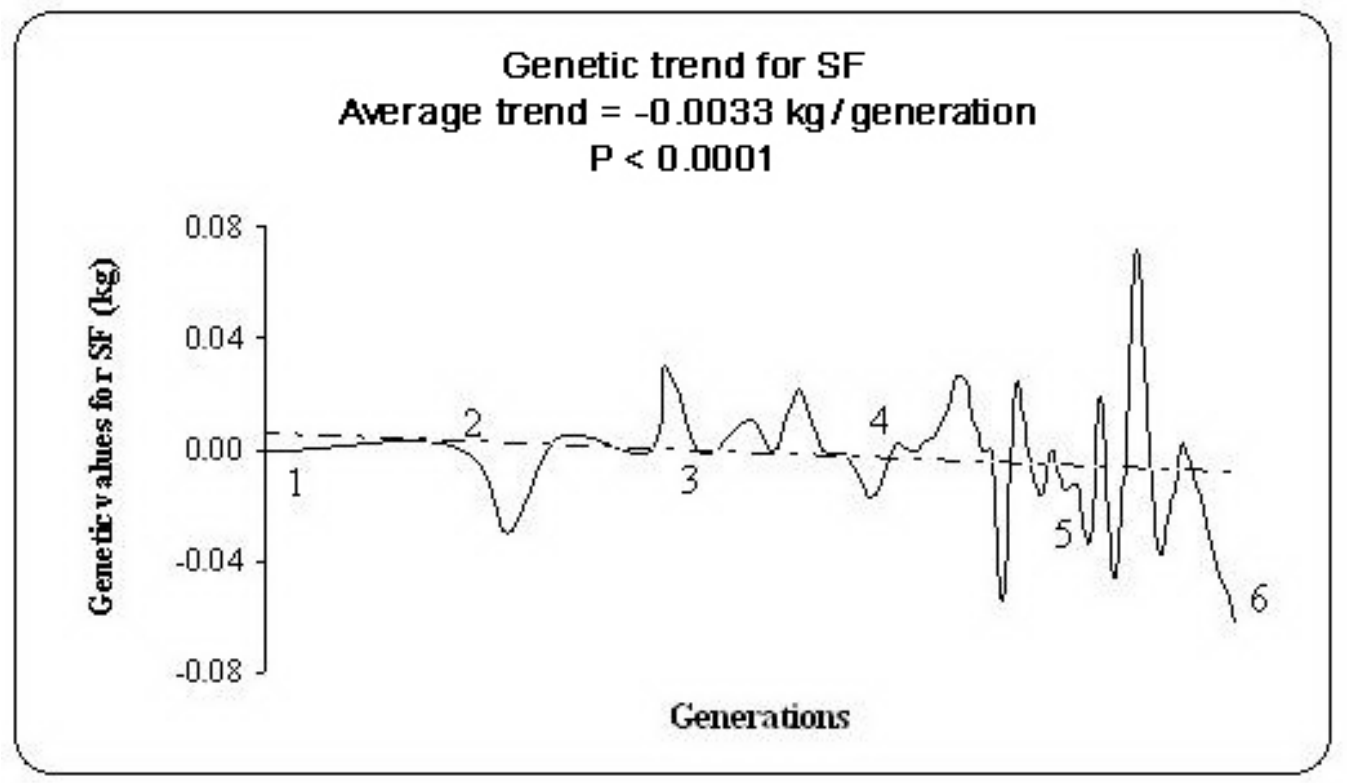

Figure 12. Genetic trend for shear force (SF) over the generations studied estimated by regression analysis. 
Generally, for the meat quality traits analyzed, a small genetic trend was observed, at least apparently, and for DL and SF the genetic trends determined were weightier. The small magnitude of the trends observed could be a consequence of the absence of selection for meat quality traits in the line analyzed, despite that Gaya (2006) had mentioned important genetic correlation estimates among the selection criteria and some of meat quality traits in this line, which could have led to correlated responses in this context, but it did not occur.

The estimates of genetic trends obtained were an indication of an improvement in the meat quality traits in the line analyzed, except for DL. However, independent of using these traits as selection criteria, they may be constantly monitored in the selection program, since some ideal limits exist for meat quality traits, where an increase in these traits can become unfavorable. For example, a very high initial $\mathrm{pH}$ or very small water loss could cause a firm and dry meat (Oda et al., 2003). Moreover, a high meat $\mathrm{pH}$ favors microbial growth (Sams, 1999), which can lead to depreciation of the quality of this meat.

Another implication of this study is emphasizing the importance of the monitoring of genetic trends for economic interesting traits in a broiler breeding program, and afterward evaluating the selection program conducted and establishing the strategies to be developed.

\section{ACKNOWLEDGMENTS}

The authors are grateful to FAPESP (State of São Paulo Research Foundation) for the financial support.

\section{REFERENCES}

Anadón HLS (2002). Biological, Nutritional, and Processing Factors Affecting Breast Meat Quality of Broilers. Doctoral thesis, Virginia Polytechnic Institute and State University, Virginia.

AviSite (2008). Produção Brasileira de Carne de Frango. Available at http://www.avisite.com.br/noticias/default.asp? codnoticia $=8648$. Accessed January 20, 2008.

Barbut S (1993). Colour measurements for evaluating the pale soft exudative (PSE) occurrence in turkey meat. Food Res. Int. 26: 39-43.

Barbut S (1997). Problem of pale soft exudative meat in broiler chickens. Br. Poult. Sci. 38: 355-358.

Boldman KG, Kriese LA, Van Vleck LD, Van Tassell CP, et al. (1995). A Manual for the Use of MTDFREML. A Set of Programs to Obtain Estimates of Variances and Covariances (Draft). ARS, USDA, USMARC, Clay Center, Lincoln.

Costa AMMA, Gaya LG, Mourão GB, Matos EC, et al. (2005). Estimativas de Tendências Genéticas do Peso do Coração e do Peso do Fígado em uma Linhagem Macho de Frangos de Corte. In: Conferência APINCO de Ciência e Tecnologia Avícolas, APINCO, Santos, 177.

Costa ARC, Lopes PS, Torres RA, Euclydes RF, et al. (2001). Tendências genéticas em características de desempenho de suínos das raças Large White, Landrace e Duroc. Rev. Bras. Zootec. 30: 348-352.

Dirinck P, Winne A, Casteels M and Frang M (1996). Studies on vitamin E and meat quality. 1. Effect of feeding high vitamin E levels on time-related pork quality. J. Agric. Food Chem. 44: 65-68.

Dransfield E and Sosnicki AA (1999). Relationship between muscle growth and poultry meat quality. Poult. Sci. 78: 743746.

Fernandez X, Sante V, Baeza E, Lebihan-Duval E, et al. (2002). Effects of the rate of muscle post mortem $\mathrm{pH}$ fall on the technological quality of turkey meat. Br. Poult. Sci. 43: 245-252.

Ferraz JB and Eler JP (2000). Sumário de Touros Marchigiana. FZEA-USP/ABCM, São Paulo.

Gaya LG (2006). Estudo Genético da Qualidade de Carne em Linhagem Macho de Frangos de Corte. Doctoral thesis, Faculdade de Zootecnia e Engenharia de Alimentos, USP, Pirassununga.

Gaya LG, Mourao GB, de Rezende FM, de Mattos EC, et al. (2005). Genetic trends of abdominal fat content in a male broiler chicken line. Genet. Mol. Res. 4: 760-764. 
Gaya LG, Ferraz JB, Rezende FM, Mourao GB, et al. (2006). Heritability and genetic correlation estimates for performance and carcass and body composition traits in a male broiler line. Poult. Sci. 85: 837-843.

Molette C, Remignon H and Babile R (2003). Effect of rate of pH fall on turkey breast meat quality. Br. Poult. Sci. 44: 787-788.

Mourão GB, Figueiredo LGG and Mattos EC (2004). Software CALGERA - Cálculo de Geração dos Animais Presentes em um Pedigree. Faculdade de Zootecnia e Engenharia de Alimentos da USP, Unpublished software, Pirassununga.

Oda SHI, Schneider J, Soares AL, Barbosa DML, et al. (2003). Detecção de cor em filés de peito de frango. Rev. Nac. Carne 28: 30-34.

Rezende FM, Gaya LG, Mourão GB, Mattos EC, et al. (2005). Estimativas de Tendências Genéticas do Peso Eviscerado e do Peso de Pernas em uma Linhagem Macho de Frango de Corte. In: Conferência APINCO de Ciência e Tecnologia Avícolas, APINCO, Santos, 160.

Sams AR (1999). Meat quality during processing. Poult. Sci. 78: 798-803.

SAS Institute (1999). Statistical Analysis Systems User's Guide. Version 8. SAS Institute Inc., Cary.

Solomon MB, Van Laack JM and Eastridge JS (1998). Biophysical basis of pale, soft, exudative (PSE) pork and poultry muscle: a review. J. Muscle Foods 9: 1-11.

Van Melis MH, Eler JP and Ferraz JBS (2001). Tendências genéticas para características produtivas e de avaliação visual em bovinos da raça Nelore. In: XXXVIII Reunião Anual da Sociedade Brasileira de Zootecnia, Piracicaba, 519520.

Wismer-Pedersen J (1959). Quality of pork in relation to rate of pH change post mortem. Food Res. 24: 711-727. 